\title{
Enhanced Lipid Stability in Whole Wheat Flour by Lipase Inactivation and Antioxidant Retention
}

\author{
Devin J. Rose \\ dev.rose@yahoo.com \\ Lynn V. Ogden \\ Michael L. Dunn \\ michael_dunn@byu.edu \\ Oscar A. Pike \\ oscar_pike@byu.edu
}

Follow this and additional works at: https://scholarsarchive.byu.edu/facpub

Part of the Food Science Commons, and the Nutrition Commons

\section{Original Publication Citation}

Rose DJ, Ogden LV, Dunn ML, and Pike O.A. "Enhanced lipid stability in whole wheat flour by lipase inactivation and antioxidant retention." Cereal Chemistry. 85.2 (28): 218-223.

\section{BYU ScholarsArchive Citation}

Rose, Devin J.; Ogden, Lynn V.; Dunn, Michael L.; and Pike, Oscar A., "Enhanced Lipid Stability in Whole Wheat Flour by Lipase Inactivation and Antioxidant Retention" (2008). Faculty Publications. 197. https://scholarsarchive.byu.edu/facpub/197 accepted for inclusion in Faculty Publications by an authorized administrator of BYU ScholarsArchive. For more information, please contact ellen_amatangelo@byu.edu. 


\title{
Enhanced Lipid Stability in Whole Wheat Flour by Lipase Inactivation and Antioxidant Retention
}

\author{
Devin J. Rose, ${ }^{1}$ Lynn V. Ogden, ${ }^{1}$ Michael L. Dunn, ${ }^{1}$ and Oscar A. Pike ${ }^{1,2}$
}

\section{ABSTRACT}

Cereal Chem. 85(2):218-223

The purpose of this study was to determine the effectiveness of dry heat, steam, and microwave treatments in decreasing lipase activity, while retaining antioxidant activity, to stabilize whole wheat flour against lipid degradation during storage. Bran was heat-treated in 230-g batches using four levels (exposure times) for each of the three treatment methods. Lipase activity and antioxidant activity were quantified for all treatment combinations. None of the treatments significantly decreased antioxidant activity; the levels determined to be optimal, inasmuch as further heating did not significantly decrease lipase activity, were $25 \mathrm{~min}$ of dry heat, 60 sec of microwave (1000W), and $60 \mathrm{sec}$ of steam. These treatments effectively decreased lipase activity by 74,93 , and $96 \%$, respectively. Optimum treatments were evaluated for acceptance using a consumer sensory panel during a 12-month storage period. No significant differences in acceptance were found between the control and any of the samples either at baseline or after storage. This suggests that whole wheat flour can be stabilized against lipolysis by utilizing the treatments described in this study without decreasing antioxidant activity, and that manufacturers may utilize these treatments without risking decreased consumer acceptance.
Consumption of whole grain products has been linked to decreased risk of cardiovascular disease, certain types of cancer, and diabetes, and an overall reduction in premature death (Lang and Jebb 2003). Indeed, the Food and Drug Administration (FDA) allows all grain-based products containing at least $51 \%$ whole grain and $<3 \mathrm{~g}$ of fat to carry the health claim "Diets rich in whole grain foods and other plant foods and low in total fat, saturated fat, and cholesterol, may help reduce the risk of heart disease and certain cancers" (FDA 1999). Based on surveys conducted by the Economic Research Service of the United States Department of Agriculture (USDA), U.S. citizens are eating the recommended servings of grain products (USDA 2000). However, the average diet falls substantially short of the recommended servings of whole grains (Kantor 1998). In 1996, only 7\% of U.S. citizens consumed the recommended three servings of whole grain products per day (USDA 2000). Today, the recommendation is for half of the daily intake of grains to come from whole grain products (USDA 2005).

One of the problems associated with whole wheat flour is its susceptibility to rancidity (Pomeranz 1992). Thus whole wheat flour requires careful stock control and storage (Galliard 1986). The shorter shelf-life of whole wheat flour compared with white flour may be attributed to nonendosperm components. These milling fractions contain high amounts of lipids and lipid-metabolizing enzymes, which may lead to a decrease in breadmaking quality (Tait and Galliard 1988), sensory acceptability (Galliard and Gallagher 1988; Hansen and Rose 1996), and nutritional value (Pomeranz 1992).

In an effort to increase shelf-life, heat treatments have been employed to inactivate lipolytic enzymes in cereal products, but results have been inconclusive. Vetrimani and Haridas Rao (1990) found that heating bran at $175^{\circ} \mathrm{C}$ for $40 \mathrm{~min}$ increased shelf-life from 20 to 90 days, and Haridas Rao et al (1980) demonstrated that the shelf-life of wheat germ could be extended from 15 to 180 days when heated at $150^{\circ} \mathrm{C}$ for $25 \mathrm{~min}$. In contrast, other researchers (Cuendet et al 1954) found no increase in the shelflife of whole wheat flour that had been autoclaved before storage, and Lehtinen et al (2003) found that the complete inactivation of lipase in oats by extrusion resulted in greater lipid oxidation.

\footnotetext{
${ }^{1}$ Department of Nutrition, Dietetics and Food Science, Brigham Young University, S-221 ESC, Provo, UT 84602.

${ }^{2}$ Corresponding author. Phone: 801-422-6671. Fax: 801-422-0258. E-mail address: oscar_pike@byu.edu
}

doi:10.1094/CCHEM-85-2-0218

(c) 2008 AACC International, Inc.
Champagne and Hron (1992) used ethanol to decrease lipase activity in rice bran, but the resulting product oxidized more rapidly. The authors in each of these cases theorized that the increase in lipid oxidation was a result of the destruction of antioxidants during treatment. Indeed, Champagne and Hron $(1993,1994)$ demonstrated that addition of an antioxidant and chelator to the ethanol during treatment resulted in a product that was stable.

The purpose of this study was to determine the effectiveness of dry heat, steam, and microwave treatments in decreasing lipase activity, while retaining antioxidant activity, to stabilize whole wheat flour against lipid degradation during storage.

\section{MATERIALS AND METHODS}

As shown in Fig. 1, the experimental design included two phases. Phase I involved determining optimum treatment levels for inactivating lipase and retaining antioxidant activity in the bran fraction of whole wheat flour. Phase II involved evaluating the optimum level of each treatment in a sensory panel over a sixmonth storage period. A subsequent evaluation was conducted with the same treatment levels to determine sensory properties and the formation of free fatty acids during 12 months of whole wheat flour storage.

\section{Phase I}

Samples and treatment. Hard red winter wheat of mixed cultivars was obtained from a local mill and tempered to $15 \%$ moisture. The resulting wheat was ground in a laboratory mill (Quadramat Jr, Brabender, Hackensack, NJ). The mill operating temperature was $30^{\circ} \mathrm{C}$, the flow rate was $85 \mathrm{~g} / \mathrm{min}$, the extraction rate was $68 \%$, and the sifter size was $236 \mu \mathrm{m}$. The mill produced two milling fractions: a flour fraction (which contained mostly endosperm) and a bran fraction (which contained mostly bran and germ).

After milling, $230 \mathrm{~g}$ of the bran fraction was subjected, in duplicate, to 1 of 12 treatment combinations as follows: dry heat for $15,20,25$, and $30 \mathrm{~min}$ using a $20 \times 3.5 \mathrm{~cm}$ (diameter $\times$ depth) aluminum pan in a forced draft oven (model 1670, Sheldon Manufacturing, Cornelius, $\mathrm{OR}$ ) at $175^{\circ} \mathrm{C}$; microwaves for 30,60 , 90 , and $120 \mathrm{sec}$ using a $14 \times 7.5 \mathrm{~cm}$ (diameter $\times$ depth) circular plastic container in a $1,000 \mathrm{~W}$ commercial microwave oven (model MA-1273M, Goldstar, Seoul, Korea) set on high power; steam for 30, 60, 90, and $120 \mathrm{sec}$ using a $150 \mu \mathrm{m}$ (No. 100) sieve, covered, and placed over a pot of boiling water. Preliminary experiments showed that these treatments did not result in any noticeable degradation such as browning. A control sample was left untreated. 
After treatment, the moisture content was determined using the Approved Method 44-19 (AACC International 2000), and bran lightness/darkness (CIE $L^{*}$ value) was measured using a spectrophotometer (ColorFlex, Hunter Associates Laboratory, Reston, VA). Samples were then freeze-dried (model 77590, Labconco, Kansas City, MO) at $46 \times 10^{-3} \mathrm{mBar}$ and $-30^{\circ} \mathrm{C}$ for $36 \mathrm{hr}$, and stored in plastic zip-top bags at $-18^{\circ} \mathrm{C}$ until measurement of lipase activity and antioxidant activity.

Lipase activity. Lipase activity was measured using a coppersoap assay (Rose and Pike 2006) with $0.6 \mathrm{~mL}$ of olive oil, 0.15 $\mathrm{mL}$ of water, and an incubation time of $4 \mathrm{hr}$ at $40^{\circ} \mathrm{C}$. After incubation, liberated fatty acids were quantified by absorbance at 715 $\mathrm{nm}$ after complexation with copper(II) ion. Lipase activity was expressed as units/gram (U/g), where $1 \mathrm{U}$ was defined as microequivalents of oleic acid liberated/hr.

Antioxidant activity and total phenolics. Bran was ground in a cyclone mill (model 3010-030, Udy Corp., Fort Collins, CO) and $200 \mathrm{mg}$ was weighed into a screw-cap centrifuge tube. Five $\mathrm{mL}$ of $80 \%(\mathrm{v} / \mathrm{v})$ ethanol was added to the tube. The headspace was flushed with nitrogen and sealed. The tube was covered with aluminum foil and shaken at high speed on a wrist-action shaker (model 75, Burrell, Pittsburgh, PA) for $4 \mathrm{hr}$. After extraction, the tubes were centrifuged (Avanti J-25, Beckman Coulter, Fullerton, CA) at 5,000 $\times g$ for $5 \mathrm{~min}$.
Antioxidant activity of the extract was measured according to the method of Marco (1968), as modified by Miller (1970), using $200 \mu \mathrm{L}$ of bran extract mixed with $5 \mathrm{~mL}$ of $\beta$-carotene/linoleate emulsion. This spectrophotometric method is based on the rate of $\beta$-carotene bleaching in the presence of linoleic acid. The initial absorbance at $470 \mathrm{~nm}$ and absorbance after $2 \mathrm{hr}$ of oxidation were used to calculate the bleaching rate (Al-Saikhan et al 1995)

$$
R=\ln \left(\frac{a}{b}\right) \times \frac{1}{t}
$$

where $R=$ bleaching rate; $a=$ initial absorbance at time zero; $b=$ absorbance at time $t ; t=$ reaction time $(2 \mathrm{hr})$.

Antioxidant activity was calculated from the bleaching rate relative to an $80 \%$ ethanol control (Al-Saikhan et al 1995) as

$$
\mathrm{AA}=\frac{R_{\text {conter }}-R_{\text {sample }}}{R_{\text {control }}} \times 100
$$

where $\mathrm{AA}=$ antioxidant activity; $R_{\text {sample }}$ and $R_{\text {control }}=$ bleaching rates of bran sample, and control, respectively.

Total phenolics were measured according to Singleton and Rossi (1965) as described by Velioglu et al (1998). Ferulic acid was used a standard instead of gallic acid because ferulic acid is the predominant phenolic compound in wheat bran (Buri et al 2004).

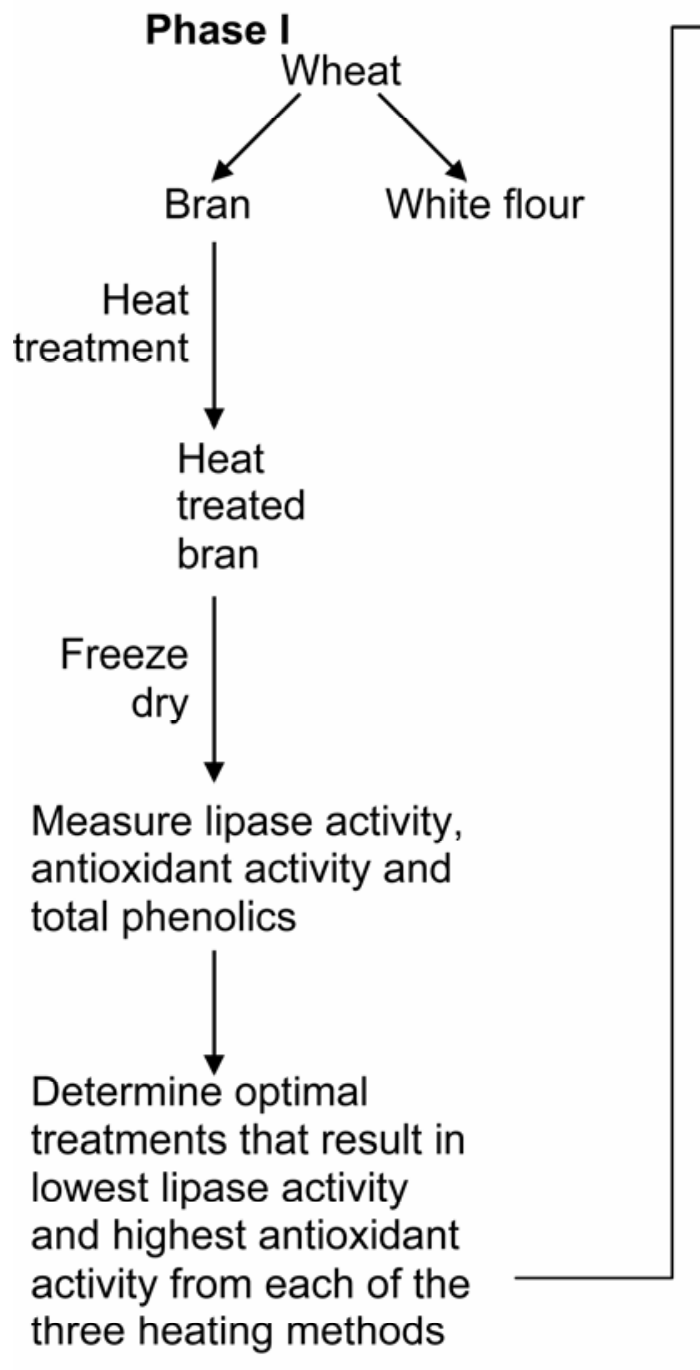

Phase I

Heat

treated

bran

Fig. 1. Experimental design of steps involved in Phases I and II.

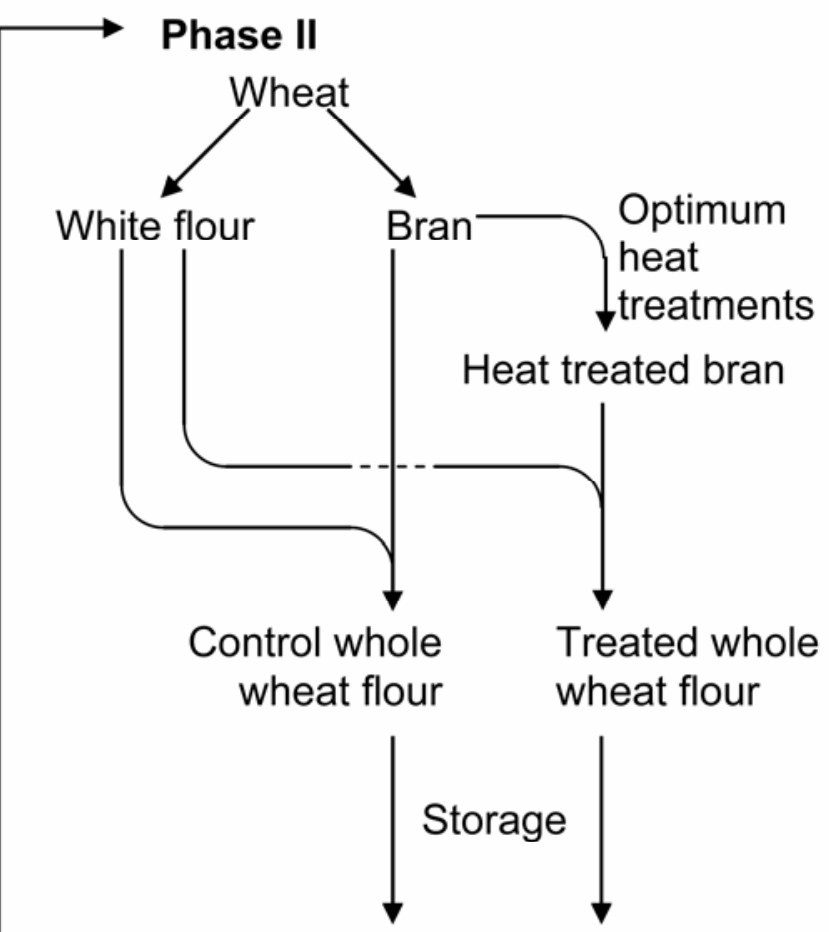

Measure free fatty acids and conjugated dienes, and run sensory panel

Compare treatments to control to determine lipid stability and consumer acceptance 
The treatment levels that resulted in the lowest lipase activity and highest antioxidant activity for each of the three heating methods were used for Phase II.

\section{Phase II}

Samples and treatment. Wheat from the same lot as that used for Phase I was tempered and ground as described above. The bran fraction was then separated into 230 -g portions, which was the largest amount that could be adequately treated at one time. Three portions (for a combined total of $690 \mathrm{~g}$, the amount required for sensory testing) were exposed to the optimal treatment level (as determined in Phase I) of each of the three heat treatments. The application of treatments to portions was duplicated. Whole wheat flour was produced by combining the heated bran fraction, or untreated control, with the flour fraction in the proper proportion. According to the Code of Federal Regulations (2003), the standard of identity requires that not less than $90 \%$ of whole wheat flour must pass through a 2.36-mm (no. 8) sieve, and not less than $50 \%$ must pass through an $850-\mu \mathrm{m}$ (no. 20) sieve. The treated whole wheat flour met these specifications; however, because bran particle size plays a major role in both baking quality (Pomeranz et al 1977; de Kock et al 1999) and storage stability (Galliard and Gallagher 1988), a major concern was obtaining bran particles of a size similar to that of commercially ground whole wheat flour. For comparison, the bran fraction of commercial whole wheat flour was separated from the flour fraction by sifting through a 300- $\mu \mathrm{m}$ (no. 50) sieve. Based on appearance at a magnification of $10 \times$, the commercial bran and the bran used in this study were virtually indistinguishable (data not shown).

Treated whole wheat flour was allowed to age in closed paper bags at $25^{\circ} \mathrm{C}$ and $60 \% \mathrm{rh}$, for two weeks, and then $776 \mathrm{~g}$ of flour was removed for baseline sensory evaluation. This short ageing time was necessary to produce acceptable flour, as freshly milled flour is unsuitable for use in breadmaking without the use of chemical maturing agents (Bass 1988). The samples were then put into long-term storage under the same conditions; aliquots were removed after three and six months of storage. Once removed from storage, the flour was placed in a plastic bag and stored at $-18^{\circ} \mathrm{C}$ until chemical or sensory analysis. A subsequent experiment was conducted on samples held for 12 months of storage.

Free fatty acids and conjugated dienes. To determine lipid degradation during storage, free fatty acids and conjugated dienes were quantified every three months during the 12 month storage study. Flour was ground in a cyclone mill. The grinding was necessary to reduce the size of the large bran particles present in whole wheat flour. After grinding, $1.5 \mathrm{~g}$ of flour was added to a $50-\mathrm{mL}$ Erlenmeyer flask, and $15 \mathrm{~mL}$ of hexane was added. The flasks were placed on an orbital shaker (model 980001, VWR Scientific, West Chester, PA) for $30 \mathrm{~min}$ at $140 \mathrm{rpm}$. After shaking, the hexane was decanted through filter paper (Whatman No. 1) into a $250-\mathrm{mL}$ round-bottom flask. The extraction was repeated twice, and the pooled extractions were evaporated on a rotary evaporator (model RE 121, Brinkmann Instruments, Westbury, CT) at $40^{\circ} \mathrm{C}$. Preliminary experiments showed that this extraction procedure did not extract all the lipids but gave values for free fatty acids that were identical to extraction from $18 \mathrm{hr}$ on a Soxhlet apparatus (Shahidi 2001). Shorter extraction procedures were used previously to measure conjugated dienes (Champagne and Hron 1992) because longer extraction procedures such as Soxhlet pose a risk of formation of conjugated dienes during the extraction procedure.

After lipid extraction, the lipids were redissolved in $10 \mathrm{~mL}$ of isooctane. A 3-mL aliquot was used for conjugated diene quantification according to Pegg (2001), using an extinction coefficient of $2.525 \times 10^{4} / \mathrm{M} / \mathrm{cm}$ at $233 \mathrm{~nm}$. A 5-mL aliquot was used for free fatty acid quantification according to Kwon and Rhee (1986), using oleic acid as the standard.
Sensory evaluation. Two sensory panels were conducted. Panel 1 evaluated the acceptance of treated and untreated product stored zero, three, and six months. In a subsequent sensory test, Panel 2 evaluated product stored for 12 months. To serve all panelists, two loaves of bread were made from each sample. Each loaf was made by combining $350 \mathrm{~g}$ of flour with $9.3 \mathrm{~g}$ of yeast, $21 \mathrm{~g}$ of sucrose, $5.3 \mathrm{~g}$ of NaCl, $10.5 \mathrm{~g}$ of shortening, and $265 \mathrm{~mL}$ of water in an electric mixer (model K5SSWW, KitchenAid, St. Joseph, MI). Dough was mixed with a dough hook for $10 \mathrm{~min}$ on speed 2, and then fermented at $30^{\circ} \mathrm{C}$ and $85 \%$ rh for $1 \mathrm{hr}$. After fermentation, dough was shaped into loaves using a mechanical sheeter and molder (National Manufacturing, Lincoln, NE), placed into $20 \times 10 \mathrm{~cm}$ bread pans and proofed for $45 \mathrm{~min}$ at $30^{\circ} \mathrm{C}$ and $85 \%$ rh. The dough was baked for $30 \mathrm{~min}$ at $200^{\circ} \mathrm{C}$ in a rotary oven (model 12/24-SS, National Manufacturing). After $1 \mathrm{hr}$ of cooling, the bread was sliced $1 \mathrm{~cm}$ thick using an electric knife and bread slicing guide (models 0332710 and 08615, respectively, Presto, Eau Claire, WI) and placed in plastic bags until served to panelists the following day.

The consumer sensory panels were conducted at the Brigham Young University Sensory Laboratory using standard procedures. Fifty panelists who frequently ate whole wheat bread were selected from the Sensory Laboratory database, which included mostly students, faculty, and staff of the university. No one involved in the study participated as a panelist. Panelists were served half a slice of bread made from each flour sample, following a randomized block design, and asked to evaluate overall acceptability, aroma, texture, flavor, and aftertaste on a 9-point hedonic scale. Each sample was identified with a randomly generated, three-digit blinding code. Panelists were monetarily compensated for their participation and data were collected using Compusense five release 4.6 software (Guelph, Ontario, Canada).

\section{Data Analyses}

Data were analyzed using Statistical Analysis System software (v.9.1, SAS Institute, Cary, NC) with a mixed model analysis of variance (PROC MIXED). Fisher's LSD was utilized to determine significant differences among means for chemical measurements. Tukey's procedure was used for the sensory data. Significant differences were defined as $P<0.05$.

\section{RESULTS AND DISCUSSION}

\section{Phase I}

Samples. The objective of this phase of the study was to produce a whole wheat flour with enhanced lipid stability that was indistinguishable from untreated flour. Therefore, mild heat treatments were selected that did not change the visual or aromatic properties of the flour. As shown in Table I, no significant differences were found in bran lightness/darkness (CIE $L^{*}$ values) for any of the treatments compared with the control.

Moisture content (Table I) varied depending on treatment. Microwave and dry heating progressively decreased the moisture content of the bran, while steam treatment increased the moisture content, as expected. However, after $24 \mathrm{hr}$, all samples had moisture contents of 10.6-12.8\%, which allowed for safe long-term storage due to the absence of excessive lipid oxidation and mold growth (Wang and Flores 1999).

Lipase activity. Table I shows the lipase activity of treated and control samples. All treatments were effective in significantly decreasing lipase activity. The levels determined to be optimal, inasmuch as further heating did not significantly decrease lipase activity, were $25 \mathrm{~min}$ of dry heat, $60 \mathrm{sec}$ of microwaves (1000W), and $60 \mathrm{sec}$ of steam. Microwave and steam treatments were more efficient at decreasing lipase activity than dry heat. While dry heat decreased lipase activity by $74 \%$ after $25 \mathrm{~min}$, microwave and steam treatments decrease lipase activity by 93 and $96 \%$, respectively, after only $60 \mathrm{sec}$. The difficulty of decreasing lipase activ- 
ity using dry heat has been reported previously (Kruger and Reed 1988; Vertimani and Haridas Rao 1990). This is likely because proteins are more stable against denaturation in a dry environment compared with a wet environment (Damodaran 1996).

Antioxidant activity and total phenolics. Total phenolics, expressed as ferulic acid, ranged from 0.980 to $1.26 \mathrm{mg} / \mathrm{g}$, and antioxidant activity ranged from 91.7 to $94.8 \%$ in heat-treated bran (Table I). These values did not change significantly $(P>0.05)$ as a result of any of the treatments and therefore total phenolics and antioxidant activity were not considered in selecting treatment levels for Phase II.

The insignificant effect of the heat treatments on antioxidant activity may be attributed to the relatively mild treatment levels, none of which produced noticeable browning. Indeed, in previous studies where increased oxidation was an issue, harsher heat treatments were used. Cuendet et al (1954) autoclaved wheat bran at $110^{\circ} \mathrm{C}$ for $1 \mathrm{hr}$, Champagne and Hron (1992) subjected brown rice to boiling ethanol vapors $\left(87^{\circ} \mathrm{C}\right)$ for up to $10 \mathrm{~min}$, and Lehtinen et al (2003) steam-heated oats for 20-40 min.

\section{Phase II}

Treatments. Dry heat for $25 \mathrm{~min}$, microwave for $60 \mathrm{sec}$, and steam for $60 \mathrm{sec}$ were chosen as the optimal treatment levels based on the results from Phase I.

Free fatty acids and conjugated dienes. The amount of free fatty acids in treated, stored whole wheat flour samples is shown in Table II. All treatments resulted in lower levels of free fatty acids after storage. The rates of free fatty acid development in each of the treated samples correlated well with the measured lipase activity. As expected from the lipase activity data, micro- wave and steam treatments were equally effective, while dry heat was moderately effective at decreasing the levels of free fatty acids in stored whole wheat flour.

Conjugated dienes (Table II) ranged from 0.418 to 0.586 $\mu \mathrm{mol} / \mathrm{g}$. While all treatments showed significant increases in conjugated dienes over the storage period, treatment effects were not significant except for dry heat at 6 and 12 months. However, this is of little practical significance in view of the sensory results discussed below. In contrast, previous reports using other treatment methods (Cuendet et al 1954; Champagne and Hron 1992; Lehtinen et al 2003) found substantial increases in lipid degradation after heat treatments. The results presented here also suggest that the methods used in Phase I to assess oxidative potential (antioxidant activity and total phenolics) were accurate.

Sensory evaluation. Mean hedonic scores for overall acceptability, flavor, texture, aftertaste, and aroma of the control and treated whole wheat bread are shown in Table III. No significant differences in hedonic scores were found between the control and any of the samples, both at baseline and after storage for up to 6 months (Panel 1). The subsequent 12-month storage study also resulted in sensory scores with no significant differences between treatments (Panel 2). At baseline, these data suggest whole wheat flour can be stabilized against lipolysis using optimized treatments of $25 \mathrm{~min}$ dry heat at $175^{\circ} \mathrm{C}$, microwave for $1 \mathrm{~min}$, or steam for 1 min, without risking consumer disapproval. Longer storage times appear to be necessary to determine whether optimal treatment levels investigated in this study will actually improve shelf stability of whole wheat flour. However, inasmuch as most whole wheat flour manufacturers stamp their product with a 6 month shelf life, our results suggest a longer shelf life is attainable.

TABLE I

CIE $L^{*}$ Values, Moisture Contents, Lipase Activity, Total Phenolics, and Antioxidant Activity of Treated Bran

\begin{tabular}{|c|c|c|c|c|c|c|}
\hline Treatment & $\operatorname{CIE} L^{*}$ & $\begin{array}{l}\text { Moisture After } \\
\text { Treatment }(\%)\end{array}$ & $\begin{array}{c}\text { Moisture } \\
\text { After } 24 \mathrm{hr}(\%)\end{array}$ & $\begin{array}{l}\text { Lipase Activity } \\
(\mathbf{U} / \mathbf{g})^{\mathrm{a}}\end{array}$ & Ferulic Acid (mg/g) & $\begin{array}{l}\text { Antioxidant } \\
\text { Activity (\%) }\end{array}$ \\
\hline None & $70.00 \mathrm{a}^{\mathrm{b}}$ & $12.83 \mathrm{c}$ & $12.38 \mathrm{bc}$ & $4.23 \mathrm{a}$ & $1.15 \mathrm{a}$ & $92.8 \mathrm{a}$ \\
\hline \multicolumn{7}{|c|}{ Dry heat, $175^{\circ} \mathrm{C}$} \\
\hline $20 \mathrm{~min}$ & $67.25 \mathrm{a}$ & $7.48 \mathrm{e}$ & $11.19 \mathrm{e}$ & $1.58 \mathrm{~d}$ & $1.22 \mathrm{a}$ & $92.6 \mathrm{a}$ \\
\hline $25 \mathrm{~min}$ & $67.45 \mathrm{a}$ & 7.86e & $11.31 \mathrm{e}$ & $1.08 \mathrm{e}$ & $1.16 \mathrm{a}$ & $94.5 \mathrm{a}$ \\
\hline $30 \min$ & $66.87 \mathrm{a}$ & $5.99 \mathrm{f}$ & $10.55 \mathrm{f}$ & $0.876 \mathrm{e}$ & $1.14 \mathrm{a}$ & $93.2 \mathrm{a}$ \\
\hline \multicolumn{7}{|c|}{ Microwaves, $1,000 \mathrm{~W}$} \\
\hline $90 \mathrm{sec}$ & $67.63 \mathrm{a}$ & $7.91 \mathrm{e}$ & $11.50 \mathrm{de}$ & $0.0762 \mathrm{f}$ & $1.16 \mathrm{a}$ & $91.9 \mathrm{a}$ \\
\hline $120 \mathrm{sec}$ & $66.40 \mathrm{a}$ & $6.04 \mathrm{f}$ & $11.10 \mathrm{e}$ & $0.0598 \mathrm{f}$ & $1.18 \mathrm{a}$ & $91.9 \mathrm{a}$ \\
\hline \multicolumn{7}{|l|}{ Steam } \\
\hline $30 \mathrm{sec}$ & $67.07 \mathrm{a}$ & $15.42 \mathrm{~b}$ & $12.28 b c$ & $2.42 b c$ & $1.06 \mathrm{a}$ & $92.2 \mathrm{a}$ \\
\hline $60 \mathrm{sec}$ & $67.12 \mathrm{a}$ & $17.52 \mathrm{a}$ & $12.35 \mathrm{bc}$ & $0.185 f$ & $1.20 \mathrm{a}$ & $93.2 \mathrm{a}$ \\
\hline $90 \mathrm{sec}$ & $67.37 \mathrm{a}$ & $17.67 \mathrm{a}$ & $12.48 \mathrm{ab}$ & $0.163 \mathrm{f}$ & $0.985 \mathrm{a}$ & $92.9 \mathrm{a}$ \\
\hline $120 \mathrm{sec}$ & $65.37 \mathrm{a}$ & $18.17 \mathrm{a}$ & $12.81 \mathrm{a}$ & $0.114 \mathrm{f}$ & $0.980 \mathrm{a}$ & $91.7 \mathrm{a}$ \\
\hline
\end{tabular}

${ }^{a} \mathrm{U}=\mu \mathrm{Eq}$ of oleic acid liberated $/ \mathrm{hr}$.

${ }^{\mathrm{b}}$ Values in each column followed by the same letter are not significantly different $(P>0.05 ; n=2)$.

TABLE II

Free Fatty Acids and Conjugated Dienes of Treated Whole Wheat Flour During Storage ${ }^{a}$

\begin{tabular}{|c|c|c|c|c|c|}
\hline \multirow{2}{*}{$\begin{array}{l}\text { Response Variable/ } \\
\text { Treatment }\end{array}$} & \multicolumn{5}{|c|}{ Storage Time (months) } \\
\hline & $\mathbf{0}$ & 3 & 6 & 9 & 12 \\
\hline \multicolumn{6}{|c|}{ Free fatty acids $(\mu \mathrm{mol} / \mathrm{g})$} \\
\hline No treatment & $0.053 \mathrm{Ea}$ & $5.16 \mathrm{Da}$ & $7.61 \mathrm{Ca}$ & $8.64 \mathrm{Ba}$ & $10.7 \mathrm{Aa}$ \\
\hline Dry heat, $25 \mathrm{~min}$ & $0.053 \mathrm{Ea}$ & $3.61 \mathrm{Db}$ & $5.44 \mathrm{Cb}$ & $6.32 \mathrm{Bb}$ & $7.58 \mathrm{Ab}$ \\
\hline Microwave, $60 \mathrm{sec}$ & $0.053 \mathrm{Ea}$ & $2.78 \mathrm{Dc}$ & $3.93 \mathrm{Cc}$ & $4.85 \mathrm{Bc}$ & $6.06 \mathrm{Ac}$ \\
\hline Steam, $60 \mathrm{sec}$ & $0.053 \mathrm{Ea}$ & $2.96 \mathrm{Dc}$ & $4.11 \mathrm{Cc}$ & $5.15 \mathrm{Bc}$ & $6.14 \mathrm{Ac}$ \\
\hline \multicolumn{6}{|c|}{ Conjugated dienes $(\mu \mathrm{mol} / \mathrm{g})$} \\
\hline No treatment & $0.418 \mathrm{Ba}$ & $0.457 \mathrm{Ba}$ & $0.433 \mathrm{Bb}$ & $0.462 \mathrm{Ba}$ & $0.528 \mathrm{Ab}$ \\
\hline Dry heat, $25 \mathrm{~min}$ & $0.418 \mathrm{Da}$ & $0.459 \mathrm{CDa}$ & $0.485 \mathrm{BCa}$ & $0.506 \mathrm{Ba}$ & $0.586 \mathrm{Aa}$ \\
\hline Microwave, $60 \mathrm{sec}$ & $0.418 \mathrm{Ca}$ & $0.435 \mathrm{BCa}$ & $0.467 \mathrm{ABab}$ & $0.492 \mathrm{Aa}$ & $0.511 \mathrm{Ab}$ \\
\hline Steam, $60 \mathrm{sec}$ & $0.418 \mathrm{Ca}$ & $0.463 \mathrm{BCa}$ & $0.447 \mathrm{BCab}$ & $0.487 \mathrm{ABa}$ & $0.522 \mathrm{Ab}$ \\
\hline
\end{tabular}

${ }^{a}$ For each response variable with the same letters within rows and the same lowercase letters within columns indicate no significant difference $(P>0.05 ; n=4)$. 
TABLE III

Sensory Panel Mean Hedonic Scores of Treated Whole Wheat Flour During Storage ${ }^{\mathrm{a}}$

\begin{tabular}{|c|c|c|c|c|c|c|}
\hline $\begin{array}{l}\text { Treatment/ } \\
\text { Storage Time (months) }\end{array}$ & $\begin{array}{c}\text { Overall } \\
\text { Acceptability }\end{array}$ & Flavor & Aftertaste & Aroma & Appearance & Texture \\
\hline \multicolumn{7}{|l|}{ Panel 1} \\
\hline \multicolumn{7}{|l|}{ No treatment } \\
\hline 3 & 7.1 & 7.1 & 6.6 & 7.1 & 7.5 & 7.3 \\
\hline 6 & 7.0 & 7.1 & 6.5 & 7.1 & 7.4 & 7.1 \\
\hline \multicolumn{7}{|l|}{ Dry heat $25 \mathrm{~min}$} \\
\hline 0 & 7.0 & 6.9 & 6.3 & 6.6 & 7.4 & 7.1 \\
\hline \multicolumn{7}{|l|}{ Microwave $60 \mathrm{sec}$} \\
\hline 0 & 7.3 & 7.1 & 6.7 & 6.9 & 7.2 & 7.0 \\
\hline 3 & 7.1 & 7.1 & 6.7 & 6.9 & 7.4 & 7.1 \\
\hline 6 & 7.2 & 7.0 & 6.5 & 7.1 & 7.4 & 7.2 \\
\hline \multicolumn{7}{|l|}{ Steam $60 \mathrm{sec}$} \\
\hline 0 & 7.1 & 7.1 & 6.7 & 6.9 & 7.3 & 7.1 \\
\hline 3 & 7.2 & 7.1 & 6.6 & 6.9 & 7.2 & 7.1 \\
\hline 12 & 6.9 & 6.8 & 6.4 & 6.9 & 7.3 & 7.1 \\
\hline \multicolumn{7}{|l|}{ Microwave $60 \mathrm{sec}$} \\
\hline 12 & 7.0 & 6.8 & 6.4 & 6.6 & 7.3 & 7.1 \\
\hline \multicolumn{7}{|l|}{ Steam $60 \mathrm{sec}$} \\
\hline 12 & 6.9 & 6.6 & 6.1 & 6.9 & 7.2 & 7.2 \\
\hline
\end{tabular}

${ }^{a}$ Scores obtained from a 9-point hedonic scale $(9=$ like extremely; $5=$ neither like nor dislike; $1=$ dislike extremely). For each panel, all scores in the same column are not significantly different $(P>0.05)$.

\section{CONCLUSIONS}

Optimum treatment levels for the bran fraction of whole wheat flour to inhibit lipase activity were dry heat at $175^{\circ} \mathrm{C}$ for $25 \mathrm{~min}$, microwaves $(1,000 \mathrm{~W})$ for $60 \mathrm{sec}$, or steam for $60 \mathrm{sec}$. These treatments may be used to decrease the development of free fatty acids in stored whole wheat flour without increasing susceptibility to oxidation. Sensory scores indicate that manufacturers may utilize these treatments without risking decreased consumer acceptance.

\section{LITERATURE CITED}

AACC International. 2000. Approved Methods of the American Association of Cereal Chemists, 10th Ed. Method 44-19. AACC International: St. Paul, MN.

Al-Saikhan, M. S., Howard, J. R., and Miller, Jr., J. C. 1995. Antioxidant activity and total phenolics in different genotypes of potato (Solanum tuberosum, L.). J. Food Sci. 60:341-343.

Bass, E. J. 1988. Wheat flour milling. Pages 1-68 in: Wheat: Chemistry and Technology, Vol. 2, 3rd Ed. Y. Pomeranz, ed. AACC International: St. Paul, MN.

Buri, R. C., von Reding, W., and Gavin, M. H. 2004. Description and characterization of wheat aleurone. Cereal Foods World 49:274-282.

Code of Federal Regulations. 2003. Cereal flours and related products. No. 21, Part 137.200. Food and Drug Administration: Washington, DC.

Champagne, E. T., and Hron, Sr., R. J. 1992. Stabilizing brown rice to lipolytic hydrolysis by ethanol vapors. Cereal Chem. 69:152-156.

Champagne, E. T., and Hron, Sr., R. J. 1993. Utilizing ethanol containing an antioxidant or chelator to produce stable brown rice products. Cereal Chem. 70:562-567.

Champagne, E. T., and Hron, Sr., R. J. 1994. Inhibition of lipase activity and oxidation in brown rice products by extraction with ethanol containing chelators/acidulants. Cereal Chem. 71:483-488.

Cuendet, L. S., Larson, E., Norris, C. G., and Geddes, W. F. 1954. The influence of moisture content and other factors on the stability of wheat flours at $37.5^{\circ} \mathrm{C}$. Cereal Chem. 31:362-389.

Damodaran, S. 1996. Amino acids, peptides, and proteins. Pages 321-429 in: Food Chemistry, 3rd Ed. O. R. Fennema, ed. Marcel Dekker: New York. de Kock, S., Taylor, J., and Taylor, J. R. N. 1999. Effect of heat treatment and particle size of different brans on loaf volume of brown bread. Lebensm. Wiss. Technol. 32:349-356.

FDA. 1999. Health claim notification for whole grain foods. Food and Drug Administration: Washington DC. Available online at: http://www. cfsan.fda.gov/ dms/ flgrains.html.

Galliard, T. 1986. Wholemeal flour and baked products: Chemical aspects of functional properties. Pages 199-215 in: Chemistry and Physics of Baking. J. M. V. Blanshard, P. J. Frazier, and T. Galliard, eds. R. Soc. Chem.: London.

Galliard, T., and Gallagher, D. M. 1988. The effects of wheat bran particle size and storage period on bran flavour and baking quality of bran/flour blends. J. Cereal Sci. 8:147-154.

Hansen, L., and Rose, M. S. 1996. Sensory acceptability is inversely related to development of fat rancidity in bread made from stored flour. J. Am. Diet. Assoc. 96:792-793.

Haridas Rao, P., Kumar, G. V., Ranga Rao, G. C. P., and Shurpalekar, S. R. 1980. Studies on the stabilization of wheat germ. Lebensm. Wiss. Technol. 13:302-307.

Kantor, L. S. 1998. A dietary assessment of the US food supply: Comparing per capita food consumption with Food Guide Pyramid serving recommendations. Agricultural Economic Report No. 72. Economic Research Service. U.S. Department of Agriculture: Washington, DC.

Kruger, J. E., and Reed, G. 1988. Enzymes and color. Pages 441-500 in: Wheat: Chemistry and Technology, Vol. 1, 3rd Ed. Y. Pomeranz, ed. AACC International: St. Paul, MN.

Kwon, D. Y., and Rhee, J. S. 1986. A simple and rapid colorimetric method for determination of free fatty acids for lipase activity. J. Am. Oil Chem. Soc. 63:89-92.

Lang, R., and Jebb, S. A. 2003. Who consumes whole grains, and how much? P. Nutr. Soc. 62:123-127.

Lehtinen, P., Kiiliäinen, K., Lehtomäki, I., and Laakso, S. 2003. Effect of heat treatment on lipid stability in processed oats. J. Cereal Sci. $37: 215-221$.

Marco, G. J. 1968. A rapid method for evaluation of antioxidants. J. Am. Oil Chem. Soc. 45:594-598.

Miller, H. E. 1970. A simplified method for the evaluation of antioxidants. J. Am. Oil Chem. Soc. 47:91.

Pegg, R. J. 2001. Determination of conjugated dienes and trienes. Pages D2.1.1-D2.1.3 in: Current Protocols in Food Analytical Chemistry. R. E. Wrolstad, ed. John Wiley and Sons: New York. 
Pomeranz, Y. 1992. Biochemical, functional, and nutritive changes during storage. Pages 55-141 in: Storage of Cereal Grains and Their Products, 4th Ed. D. B. Sauer, ed. AACC International: St. Paul, MN.

Pomeranz, Y., Shogren, M. D., Finney, K. F., and Bechtel, D. B. 1977. Fiber in breadmaking-Effects on functional properties. Cereal Chem. 54:25-41.

Rose, D. J., and Pike, O. A. 2006. A simple method to measure lipase activity in wheat and wheat bran as an estimation of storage quality. J. Am. Oil Chem. Soc. 83:415-419.

Shahidi, F. 2001. Solvent extraction of oilseeds, nutmeg, and other foods using the Soxhlet method. Pages D1.1.1-3 in: Current Protocols in Food Analytical Chemistry. R. E. Wrolstad, ed. John Wiley and Sons: New York.

Singleton, V. L., and Rossi, Jr., J. A. 1965. Colorimetry of total phenolics with phosphomolybdic-phosphotungstic acid reagents. Am. J. Enol.
Vitic. 16:144-158.

Tait, S. P. C., and Galliard, T. 1988. Effect on baking quality of changes in lipid composition during wholemeal storage. J. Cereal Sci. 8:125-137.

USDA. 2000. U.S. Agriculture: Food Consumption in America. Pages 210 in: Agriculture Fact Book. United States Department of Agriculture: Washington, DC.

USDA. 2005. MyPyramid.gov. Available online: http://www.my pyramid. gov. United States Department of Agriculture: Washington DC.

Velioglu, Y. S., Mazza, G., Gao, L., and Oomak, B. D. 1998. Antioxidant activity and total phenolics in selected fruits, vegetables, and grain products. J. Agric. Food Chem. 46:4113-4117.

Vetrimani, R., and Haridas Rao, P. 1990. Studies on the stabilization of wheat bran. J. Food Sci. Technol. Mys. 27:332-335.

Wang, L., and Flores, R. A. 1999. The effects of storage on flour quality and baking performance. Food Rev. Int. 15:215-234.

[Received June 11, 2007. Accepted October 1, 2007.] 